\title{
Jesus and Suffering
}

\section{Introduction}

What death is more shameful than to be crucified? What death worse than this condemnation is conceivable? Even now he remains a reproach among all who have not yet received faith in him. ${ }^{1}$

But if he was really so great he ought, in order to display his divinity, to have disappeared suddenly from the cross. ${ }^{2}$

As can be seen from the first quotation above, Jesus' crucifixion and death posed a problem for the early Christian writers. For Celsus, on the other hand, it was a reason to have contempt for Christians. Jesus' death was also problematic for his masculinity, since the crucifixion and his manner of dying were potentially shameful. In all three of the Synoptic Gospels, the trial and crucifixion are "the ultimate public settings for the shaming of Jesus." ${ }^{3}$ Throughout the passion narratives, Jesus is the object of humiliating practices. Jesus is arrested, bound, scourged, and crucified. As Celsus' example shows, for outsiders presenting a crucified man as the ideal was nonsense or crazy. ${ }^{4}$ In this chapter, I study Jesus' passion predictions and the passion narratives, from the Gethsemane account to the crucifixion and the death of Jesus. The Gospels of Mark and Matthew present Jesus as abandoned by his followers and dying alone, whereas Luke's passion narrative is less negative in its presentation of Jesus. In Mark and Matthew, mocking and failure dominate the passion narrative, while forgiveness and clemency are central in Luke's account. ${ }^{5}$ I begin by briefly studying what the ancient Greco-Roman philosophers wrote about death and suffering. This discussion was closely connected with the ideals of masculinity.

1 Eusebius, Praep. ev. 10.8, in Oden \& Hall (ed.) 1998, 218.

2 Origen, Cels. 2.68. Transl. Henry Chadwick.

3 Rhoads, Dewey \& Michie 1999, 71.

4 Cf. 1 Cor 1:23.

5 See also Brown 1994a, 26-30. 


\section{Death and Suffering in the Ancient Greco-Roman World}

Especially for the Stoic philosophers, enduring pain and death were important signs of masculinity. Cicero argues: "man's peculiar virtue is fortitude, of which there are two main functions, namely scorn of death and scorn of pain. These then we must exercise if we wish to prove possessors of virtue, or rather, since the word for 'virtue' (virtus) is borrowed from the word for 'man' (vir), if we wish to be men."6

The proper attitude to death and the right way of dying were commonly discussed in ancient Greco-Roman philosophical treatises. ${ }^{7}$ Philosophers maintained that wise men were not afraid of death. ${ }^{8}$ A noble, fearless death was a way of showing masculinity. Its most important characteristic was manliness ( $\dot{\alpha} \vee \delta \rho \varepsilon i \alpha)$, but a noble death was not limited to men. As mentioned in Chapter 2, women could also display $\alpha \dot{v} \delta \rho \varepsilon i \alpha$ and become masculine. For women, however, a noble death was a sign of their exceptional character. ${ }^{9}$ The deaths of Socrates and Seneca were commonly invoked as examples of the noble death. ${ }^{10}$ Other examples included Zeno and Anaxarchus, who died while resisting tyrants. ${ }^{11}$ The tradition of the noble death can also be found in the Jewish martyrdom stories, especially in 2 and 4 Maccabees. ${ }^{12}$

The ideal of a noble death was related to the idea of how a man was supposed to behave when in pain or being tortured. Complaining about pain was considered feminine. Cicero argues that courage (fortitudo) forbids "a man to show womanish weakness in pain."13 The ideal was to endure hardships

6 Cicero, Tusc. 2.43: "viri autem propria maxime est fortitudo, cuius munera duo sunt maxima mortis dolorisque contemptio. Utendum est igitur his, si virtutis compotes vel potius si viri volumus esse, quoniam a viris virtus nomen est mutuata." Transl. J. E. King. See also Cicero, Tusc. 2.50-51; Seneca, Ep. 24.14.

7 On the tradition of the noble death in the ancient Greco-Roman world, see Droge \& Tabor 1992; Seeley 1990; Henten \& Avemarie 2002.

8 See, e.g., Plato, Phaed. 67e; Cicero, Tusc. 2.2; Epicurus to Menoeceus; Epictetus, Diatr. 1.1.23-25; Ammianus Marcellinus 14.9.6.

9 See, e.g., Josephus, Ant. 15.235-236, where Mariamme's noble lineage can be seen in her calm death. See also Conway 2008, 71-72.

$10 \quad$ Plato, Phaed. 117d-e; Cicero, Tusc. 1.102; Seneca, Ep. 24.4-8; Plutarch, On Tranquility of Mind 475E; Epictetus, Diatr. 1.29.18; 2.2.15; 3.23.21; Ench. 53.4; Tacitus, Ann. 1.53; 15.6o-64.

11 See, e.g., Diogenes Laertius 9.27; 9.59; Plutarch, Reply to Colotes 1126D; Philo, Worse 176; Good Person 106-109. See also Sterling 2001, 385-389.

12 E.g., 2 Macc 6-7; 4 Macc 5-7. See also Sterling 2001, 391-392.

13 Cicero, Fin. 2.94: "effeminari virum vetant in dolore." Transl. H. Rackham. 
without complaining or giving in. ${ }^{14}$ This showed masculine steadfastness and the self-control of a man. Torture is a common part of the accounts of philosophers and martyrs dying at the hands of tyrants. Tortured heroes do not cry out in pain. This can be seen, for instance, in 4 Maccabees, where Eleazar and the seven boys condemn the tyrant Antiochus and pray to God while they are being tortured. ${ }^{15}$ However, as was noted already in Chapter 2 , there also existed a competing, self-assertive ideal that a man should revenge wrongs that happen to him. For example, in Plato's Gorgias Callicles argues that "endurance of wrong done is not a man's part at all, but a poor slave's."16 Brent Shaw notes that the equation of nobility and passive endurance was seen as womanish by the dominant culture. ${ }^{17}$ In ancient Greco-Roman writings, evidence can be found for both self-controlled and self-assertive ideals of masculinity concerning how a man was to behave regarding suffering and death. Compared with these ancient Greco-Roman ideals, how do the Synoptic Gospels present Jesus' suffering and death?

\section{Jesus' Teaching on Suffering}

In the Synoptic Gospels, Jesus predicts his suffering and death on three occasions. ${ }^{18}$ The contents of the predictions are similar. Jesus will suffer and die, but also be resurrected on the third day. None of the passion predictions tell how Jesus is going to behave in the course of his abuse and death. The predictions list what is going to happen to him: physical and verbal abuse and death. It is thus difficult to ascertain whether Jesus' behavior is going to be masculine or not, but it seems that Jesus will endure abuse and death, not fight

14 See, e.g., Seneca, Ep. 78.15-19. This ideal can be found in the Jewish writings as well. In Mart. Isa. 5.14 it is said: "while Isaiah was being sawed in half, he did not cry out, or weep, but his mouth spoke with the Holy Spirit until he was sawed in two." Transl. M. A. Knibb.

154 Macc 5:16-38; 6:17-29; 9:15-12:19. For the manner in which martyrs were supposed to face death, see also 2 Macc 6-7; Acts 6:8-7:60; Mart. Pol. 5 .

16 Plato, Gorg. 483a-b. Transl. W. R. M. Lamb. Hobbs 2000, 138-140. The philosophical tradition of endurance and noble death is made fun of in the ancient novels. In Chariton's Chaereas and Callirhoe 4.3, self-control is out of place when an innocent man remains silent during crucifixion. In Achilles Tatius' Leucippe and Clitophon 5.23, the main character Clitophon gets tired of "philosophizing" (suffering in silence) when being beaten. This is a satirical presentation of the philosophical ideal of stoically bearing a beating.

17 Shaw 1996, 279.

18 Mark 8:31; 9:31; 10:33-34; Matt 16:21; 17:22-23; 20:18-19; Luke 9:22, 44; 18:31-33. Matthew adds another short passion prediction in Matthew 26:1-2. 
against it. In Mark, the teaching is always followed by the disciples not understanding Jesus, which gives Jesus the occasion to offer further teaching on the nature of discipleship. This structure is less evident in Matthew and Luke. Only the first passion prediction is followed by Jesus teaching on how the disciples should view suffering. ${ }^{19}$ This is why I focus here on the first passion prediction and the subsequent teaching on suffering. The disciples are called to endure suffering as an inevitable part of discipleship.

In all three Synoptic Gospels, the first passion prediction follows Peter's confession of Jesus as the Messiah. As mentioned in Chapter 4, Peter's conception of messiahship seems to be flawed. The Messiah confession is followed by a teaching that is a redefinition of messiahship: Jesus is the Messiah, but not the kind of Messiah the disciples expect. The three passion predictions aim to counter the disciples' view of the Messiah as a strong and powerful military leader, that is, their self-assertive ideal of masculinity. Instead, Jesus presents the figure of the suffering Messiah. In all of the Synoptic Gospels, Jesus' death is a divinely decreed necessity. He must ( $\delta \varepsilon \hat{\imath})$ die (Mark 8:31; Matt 16:21; Luke 9:22). Later, the Gospel accounts show Jesus following his own teaching when he does not try to escape from death. Jesus' acceptance of his suffering and death makes him an exemplary figure. The disciples' behavior after the passion predictions contrasts them with Jesus' decisive attitude regarding his death. For example, after the first passion prediction, Peter rebukes Jesus in Mark and Matthew. Matthew adds that the disciples were sad after the second prediction (Matt 17:23). Although Jesus' assertion of his suffering is incompatible with the self-assertive ideal of masculinity, his teaching is in line with the self-controlled ideal of the noble, masculine death.

This redefinition of messiahship is followed by a redefinition of discipleship. Jesus' followers should accept the necessity of suffering: "If any want to become my followers, let them deny themselves and take up their cross and follow me" (Mark 8:34; Matt 16:24; Luke 9:23). The followers of Jesus should deny their own interests and concern for their well-being. Remaining loyal to Jesus should surpass all other concerns. The outcome of taking up their cross may mean the loss of their lives. ${ }^{20}$

Jesus teaches the acceptance and endurance of suffering. Jesus' passion predictions are thus compatible with the rhetoric of the noble death tradition.

19 The misunderstandings after the second and third predictions (that is, the question of who is the greatest and the request of John and James) were studied earlier in Chapter 4. It is possible that Mark and Matthew literally mean cross-bearing and martyrdom. Luke, on the other hand, softens the expression. In Luke, "taking up the cross" is transformed from literal martyrdom into a metaphor by the addition of the word "daily" ( $\left.\varkappa \alpha \theta^{\prime} \dot{\eta} \mu \varepsilon \dot{\varepsilon} \rho \alpha\right)$. 
This would make his death masculine from the point of view of the selfcontrolled ideal of masculinity. However, in Mark, Jesus notes another possibility: someone might consider his death shameful (Mark 8:38): "Those who are ashamed of me and of my words in this adulterous and sinful generation, of them the son of man will also be ashamed when he comes in the glory of his Father with the holy angels." Accordingly, it is not self-evident that Jesus' death would be regarded as a noble, masculine death. Death by crucifixion was normally considered shameful. Jesus combats this view by maintaining that it is in fact those who are ashamed of his death that will later be shamed themselves. They are also part of the adulterous and sinful generation. As seen earlier, adultery was regarded as effeminate in the ancient Greco-Roman world. ${ }^{21}$ Thus, whoever is ashamed of Jesus is not masculine in the right way. Those who are masculine in the right way should expect a negative judgment from the surrounding culture. Mark thus offers a redefinition of what is masculine and recommends a voluntarily marginal position for the disciples. Matthew and Luke tone down the teaching, but this has less to do with their depiction of the disciples' masculinity than a wish to enhance the portrayal of Jesus and preserve his masculinity. This is especially the case with Matthew, who omits any mention of the shamefulness of Jesus' death.

Jesus also instructs his disciples on how the disciples should behave when they face persecution and potential martyrdom (Matt 5:11-12; 10:16-42; 24:9; Mark 13:9-13; Luke 21:12-19). The disciples are going to be handed over to councils, flogged in synagogues, and dragged before governors and kings. All three

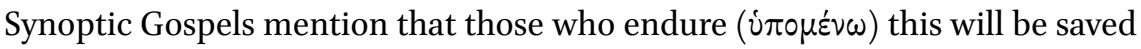
(Matt 10:22; 24:13; Mark 13:13; Luke 21:19). The disciples should not resist suffering, but endure it with patience. The Synoptic Gospels are thus closer to the Stoic philosophical ideal of endurance than the self-assertive ideal that a man should revenge the wrongs he suffers.

\section{Jesus in Gethsemane}

Let us examine next the passion narratives, starting with the Gethsemane accounts. How does Jesus' behavior in the passion narratives relate to the competing hegemonic ideals of masculine behavior? I study the Gethsemane accounts of each Synoptic Gospel separately.

21 See above Chapter 3. See also Conway 2008, 97. 


\section{Mark 14:32-42}

Jesus has prophesied his death previously in Mark's Gospel, but in Gethsemane Jesus' resolve seems to crumble. ${ }^{22}$ The emotions that Jesus expresses in Gethsemane are not in accordance with either the self-assertive or the selfcontrolled ideals of masculine behavior. Mark uses strong and emotional language to describe Jesus (Mark 14:33). The narrator portrays Jesus as "being

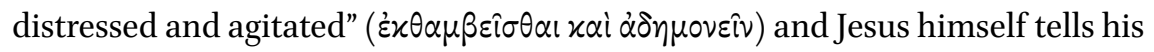
disciples he is "deeply grieved" ( $\pi \varepsilon p i(\lambda v \pi \circ \varsigma)$.'Ex $\theta \alpha \mu \beta \varepsilon \hat{\sigma} \sigma \theta \alpha$, "to be overwhelmed," describes great emotional turmoil. This is the only time in the Gospel that this verb is used to describe Jesus. It is used elsewhere to portray the amazement of the crowds and the disciples when they witness Jesus' miracles or teaching (Mark 1:27; 9:15; 10:24). Here the meaning of the verb is closer to distress or anguish. ${ }^{23}$ 'A $\eta \eta \mu o v \varepsilon i v$, "be in anxiety, be distressed, troubled," also refers to great anguish. ${ }^{24}$ The two verbs express very strong emotions.

Jesus' posture also highlights his emotional state. He falls on the ground (Mark 14:35). The past tenses of falling ( $\tilde{\varepsilon}^{\prime \prime} \pi(\pi \tau \varepsilon v)$, saying ( $\left(\varepsilon^{\prime \prime} \lambda \varepsilon \vee \varepsilon \nu\right)$, and praying

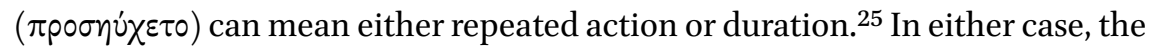
verbs highlight the magnitude of Jesus' distress. These excessive emotions also feminize Jesus. ${ }^{26}$ Jesus' emotion and his behavior are in contrast with his previous demeanor in the passion predictions. As we have seen, Jesus' emotional behavior is also in contrast with the calm manner in which martyrs were expected to face death.

Mark notes that Jesus "began to" be distressed (Mark 14:33). From the Stoic perspective, it is possible that Jesus only began to feel pre-emotion, the initial involuntary reaction, but did not allow it to develop into full emotion. ${ }^{27}$ However, Mark often uses the construction "began to" in an auxiliary sense. ${ }^{28}$ Moreover, Jesus' own words make clear that he actually feels deeply grieved (Mark 14:34). Therefore, one can conclude that Mark portrays Jesus as emotion$\mathrm{al}$, not just experiencing a pre-emotion. The presentation of Jesus as emotional

\footnotetext{
22 Marcus 2009, 982; Placher 2010, 206; Thurman 2003, 150.

23 Blaising 1979, 335; Evans 2001, 409; Holleran 1973, 12; Marcus 2009, 983; Myers 2008, 366.

24 Blaising 1979, 336; Myers 2008, 366; Voorwinde 2011, 48.

25 Holleran argues that the expression should be taken as meaning repeated action and not duration. Holleran 1973, 19, 22.

26 See also Thurman 2007, 200.

27 This is how the early Christian theologians Origen and Jerome understood Matthew's text. They argue that Jesus only began to be overwhelmed, but did not arrive at that state. Origen, Comm. Matt. 90; Jerome, Comm. Matt. 4.26.37. See also Layton 2000, 268-269; Stowers 2010, 72-73.

28 Mark 6:7; 10:28; 11:15.
} 
elsewhere in the Gospel supports this interpretation as well. ${ }^{29}$ Mark's Jesus does not demonstrate the Stoic ideal of $\dot{\alpha} \pi \dot{\alpha} \theta \varepsilon 1 \alpha$ or self-control of emotions.

Jesus' prayer is described first in indirect, then in direct discourse (Mark 14:35-36). In indirect discourse, Mark tells that Jesus prayed for the hour to

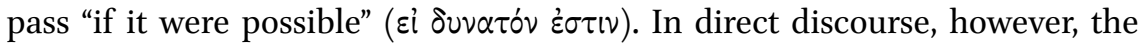
condition is changed into a statement: "Abba, Father, for you all things are pos-

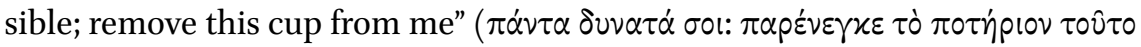
$\left.\dot{\alpha} \pi^{\prime} \xi \mu 0 \hat{)}\right)$. Mark comments that the next time Jesus prays "saying the same

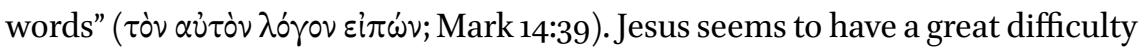
in accepting his fate. In the end, however, Jesus resigns to God's will.

Robert Gundry argues that Mark's intention is to "counter the scandal of the Cross" by presenting Jesus as strong. ${ }^{30}$ In contrast to the disciples, who keep falling asleep and do not stay awake to pray, Jesus does appear strong. His prayer exhibits his piety. However, Mark could have emphasized the strength of Jesus in some other way than portraying Jesus praying in agony for the cup to pass. For example, he could have employed the noble death tradition, which would have portrayed Jesus as more obviously strong and masculine. Mark could have portrayed Jesus as readily accepting suffering. Although suffering may be a divine necessity and endurance may be the ideal, Mark also highlights that endurance and the acceptance of suffering are not easy.

Jesus does not embrace his death calmly like Socrates or the Maccabean martyrs. For example, the Maccabean martyrs ask their torturers "Why do you delay?" in response to the suggestion that the torture would stop if the martyrs ate defiling foods (4 Macc 9:1). Jesus does not deliver a noble martyr's speech; instead, he decidedly does not want to die. Accordingly, Mark's presentation was seen as problematic by non-Christians as well as later Gospel writers and early Christian theologians. For Celsus, the mourning and lamentation of Jesus were proof that he was not divine..$^{31}$ The early Christian writers tried to salvage the Gospel accounts by claiming that Jesus was in fact in control of his emotions. Jerome and Hilary of Poitiers argue that Jesus did not feel sorrow for himself, but for his disciples or because of the rejection of the Jewish people. ${ }^{32}$ As we will see, the scene was also problematic for Mark's first known readers, Matthew and Luke. Luke omits the Markan references to Jesus' emotions and

\footnotetext{
29 Cf. Chapter 6.

$30 \quad$ Gundry 1993,856 .

31 Origen, Cels. 2.24. See also Theodore of Mopsuestia, in Ev. Lucae comm. Fragmenta, PG 66.724; quoted in Luz 2005, 394.

32 See Jerome, Comm. Matt. 4.26.37 and Hilary of Poitiers, on Matthew 31.4, in Simonetti (ed.) 2002, 254-255.
} 
depicts him as pious and in control of events. Matthew also alters the account, but his changes are more subtle.

\section{Matthew 26:36-46}

Compared with Mark's Gospel, Matthew has very few references to Jesus' emotions before the Gethsemane scene. The fact that few emotions are mentioned before this pericope makes the emotions in this pericope stand out in sharp relief. In comparison to Mark, Matthew still tones down the portrayal of Jesus' agony. According to Matthew, Jesus "began to be grieved and agitated"

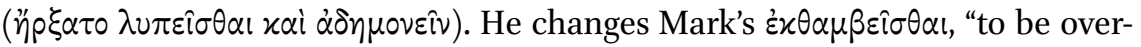
whelmed," to $\lambda v \pi \varepsilon i \sigma \theta \alpha$, "to grieve." This makes the Markan phrase slightly milder. ${ }^{33}$ Matthew's Jesus is grieved in comparison to Mark's anguish and terror. While $\lambda v \pi \varepsilon i \hat{\sigma} \theta \alpha$ is is commonly used to express sorrow, this is the first occasion in Matthew where it is used to describe Jesus. ${ }^{34}$ In Matthew 26:39, Jesus

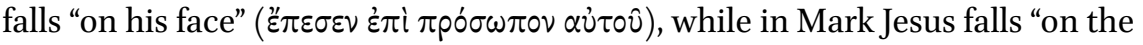
ground" (है $\pi(\pi \tau \varepsilon \nu \dot{\varepsilon} \pi \dot{\imath} \tau \hat{\eta} \varsigma \gamma \hat{\eta} \varsigma)$. Both expressions paint a picture of desperation and anguish. Matthew partly tones down Mark's description of Jesus emotions, but he does not do this systematically. In the end, Matthew does not seem to see Mark's account as very problematic.

A more substantial alteration is found in Matthew's depiction of the prayers of Jesus. Matthew changes Mark's prayer from a statement into a condition: "if it is possible, let this cup pass from me" (Matt 26:39). In this way, Matthew combines Mark's indirect and direct discourses, thus making the account shorter. At the same time, he also tones down Jesus' prayer. By leaving out "everything is possible to you," Matthew changes the prayer into one of submission. ${ }^{35}$ Craig

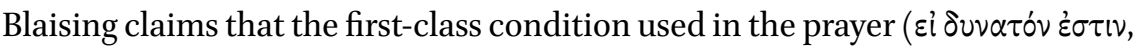
$\left.\pi \alpha \rho \varepsilon \lambda \theta \dot{\alpha} \tau \omega \dot{\alpha} \pi^{\prime} \dot{\varepsilon} \mu 0 \hat{v} \tau \dot{0} \pi 0 \tau \eta^{\prime} \rho 10 \nu \tau \tau 0 \hat{\tau} \tau\right)$ assumes that the condition is a real possibility. Therefore, Blaising argues that the cup passing from Jesus would actually be God's will. ${ }^{36}$ However, a first-class condition does not imply whether the condition is real or not. The conditional sentence of the first type sets forth "the conclusion as real, if the condition be real—but implies nothing as to the latter." ${ }^{37}$ Accordingly, it is more likely that the cup passing from Jesus

\footnotetext{
33 Beare 1981, 514; Blaising 1979, 335; Holleran 1973, 71; Voorwinde 2011, 112.

34 Cf. Matt 14:9; 17:23; 18:31; 19:22; 26:22.

35 Gould 1948, 271; Nolland 2005, 1099.

36 Blaising 1979, 337, quoting A. T. Robertson, A Grammar of the Greek New Testament: "This class of condition assumes the condition to be a reality and the conclusion follows logically and naturally from that assumption."

Kaegi 2007, 144. See also Hagner 1995, 783.
} 
would not be God's will, but Jesus' desire. In the end, Jesus submits to God's will. Richard Sorabji notes that the Stoic philosophers maintained that the wise person should qualify their desires and expectations with reservation (for example "if God wills," or "if nothing prevents"). ${ }^{38}$ In this way, the wise person avoids disappointment if things happen differently. Matthew's change moves the request closer to the Stoic ideals.

In Mark, Jesus prays the second and third times using the same words as in the first prayer; that is, he is praying for the cup to pass. In Matthew, the second prayer is different from the first. Jesus quotes the prayer he has taught his disciples: "My Father, if this cannot pass unless I drink it, your will be done" (Matt 26:42; cf. Matt 6:10). Jesus' obedience is emphasized. He prays like he has taught his disciples. ${ }^{39}$ It is only when describing the third prayer that Matthew tells that Jesus prays by "saying the same words" ( Matt 26:44). Thus, the prayer that Jesus repeats is not the plea for deliverance, but rather the second prayer that God's will be done. As a result, there is less struggle in Matthew than in Mark. Jesus submits to the divine will already in the second prayer. Matthew is closer to the noble death tradition than Mark and, accordingly, he also makes Jesus more masculine, at least from the point of view of the self-controlled ideal of masculinity. From the point of view of the self-assertive ideal, Jesus would not be masculine in Matthew's Gospel, since in the end he does not attempt to fight back.

\section{Luke 22:39-46}

Luke changes Mark's version even more than Matthew by emphasizing the calmness of Jesus. No mention of Jesus' emotions is made. The emotions are transferred to the disciples (Luke 22:45). Their emotion is understandable, but it is still a sign that they are lower in the masculinity hierarchy than Jesus. Luke also emphasizes Jesus' piety. Jesus goes away to pray only once and he kneels reverently instead of throwing himself to the ground. Luke also changes the content of the prayer, stressing God's will: "if you are willing, remove this cup

38 Sorabji 2000, 53-54. See, e.g., Seneca, Tranq. 13.2-3: "I will set sail unless anything happens to prevent me, I shall be praetor, if nothing hinders me, my financial operations will succeed, unless anything goes wrong with them. This is why we say that nothing befalls the wise man which he did not expect." Transl. John W. Basore. See also Epictetus, Diatr. 2.6.9-10; 4.1.89-9o; Ench. 4; cf. Jas 4:13-17.

Barbour 1969/1970, 238; Beare 1981, 515; Luz 2005, 397. 


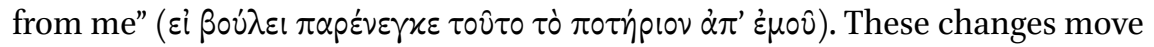
the account close to the ideal of the noble, masculine death. ${ }^{40}$

Although the account is generally stripped of emotions, in some manuscripts Jesus receives heavenly reassurance in the form of an angel (Luke 22:4344): "Then an angel from heaven appeared to him and gave him strength. In his anguish $\left(\dot{\alpha} \gamma \omega v^{\prime} \alpha\right)$ he prayed more earnestly, and his sweat became like great drops of blood falling down on the ground."41 The word $\alpha \gamma \omega v i \alpha$ refers to fear and anguish (Luke 22:44).42 This adds an emotional element to the portrayal of Jesus. These verses bring the depiction of Jesus more in line with the other Synoptic Gospel presentations.

Nevertheless, verses $43^{-44}$ are most likely a later interpolation. The verses are absent from the oldest manuscripts of Luke. The length of the passage makes an accidental omission unlikely. ${ }^{43}$ Moreover, the verses add an emotional tone to an otherwise restrained account of Jesus' behavior in Gethsemane. ${ }^{44}$ Luke does not reference Jesus' distress or include the prayer for the hour to pass. In the previous chapter, we saw that Luke omits the mentions of Jesus' emotions elsewhere in the Gospel as well. In addition, as we shall see, during the rest of the passion narrative Luke presents Jesus in control of events and his emotions. ${ }^{45}$ Given the calmness of Jesus in the face of death, verses 43-44 appear intrusive. Since the absence of these verses fits better with the overall narrative of Luke's Gospel, it is more likely that they did not originally belong to it. The tradition behind these verses itself must be early, however, since Justin Martyr already shows knowledge of it. ${ }^{46}$ Bart Ehrman and Mark Plunkett suggest that the verses were added to Luke as an anti-Docetic polemic emphasizing the humanity of Jesus. ${ }^{47}$ There is thus no struggle in Luke, and Jesus accepts the necessity of his suffering faster than in Mark or Matthew. Luke is closer to the noble death tradition than either Mark or Matthew. This

40 Wilson $(2015,214)$ argues that since Luke retains Jesus' plea for the removal of the cup, Luke's portrayal of Jesus is also unmasculine and in opposition to the ideal of the noble death. However, Wilson does not pay attention to Luke's change of wording. Luke adds an important condition: if God is willing. These two words ( $\varepsilon i$ ß the sentence. Jesus' prayer emphasizes his masculine piety. The verses are omitted, for example, in $\mathrm{p}^{75} \boldsymbol{\aleph}^{1}$ A B N T W 5791071844 and included in $\aleph^{*}, 2$ D L $\Theta \Psi$ 0171. See Ehrman \& Plunkett 1983, 402-403.

Stauffer 1964, 140.

43 Ehrman \& Plunkett 1983, 403-404; Marshall 1978, 831-832.

44 See also Nolland 1993, 1080; Sterling 2001, 396.

45 See also Ehrman \& Plunkett 1983, 411.

46 Justin, Dial. 103.8.

47 Ehrman \& Plunkett 1983, 407-408. See also Metzger 1994, 151. 
makes Luke complicit with the philosophical ideal masculinity of self-control and endurance.

\section{The Masculinity of Jesus in Gethsemane}

In sum, Luke's account is closest to the ideal of the noble, masculine death, whereas Mark's account is furthest away from that ideal. In Mark, Jesus prays to God to "remove the cup." Jesus does not act like the philosophers or the Maccabean martyrs approaching their death calmly. Conway notes that if there were a masculine aspect in Mark's account, it would be in the "heroic overcoming of the passions" that Jesus manifests. ${ }^{48}$ However, the account would have an even more masculine aspect if there was no struggle and overcoming of passions at all. It is unlikely that Mark's portrayal of Jesus would have been seen as masculine by either those who maintained that a man should be in control or those who maintained that a man should endure suffering with patience.

Matthew and especially Luke emend Mark's account by bringing it closer to the ideal of noble death. Nevertheless, they do not go so far as John, who echoes the Synoptic accounts of Gethsemane while at the same time disagreeing with them. In John 12:27, Jesus says: "Now my soul is troubled. And what should I say-'Father, save me from this hour'? No, it is for this reason that I have come to this hour." The anguished prayer in Mark and Matthew is transformed into a rhetorical question. ${ }^{49}$ In John, Jesus does not face a struggle of trying to accept his fate.

Conway argues that the Gethsemane account shows the relativity of the gender gradient in the ancient world. In relation to God as the "ultimate masculine figure," Jesus cannot be the stronger one. Jesus maintains a submissive posture throughout the arrest and trial, not only vis-à-vis God but other people as well..$^{50}$ As we have seen in earlier chapters, obeying God's will was part of the ideal masculinity of the Synoptic Gospels. Nevertheless, would it not have been enough for Jesus to be submissive to God but not to other people? The relativity of the gender gradient does not explain why Jesus is submissive to other people. Luke shows that Jesus can remain in control of events even while submitting to God's will. Luke is again closest to the hegemonic ideals, whereas Mark and Matthew seem to advocate a more marginal ideal of masculinity.

48 Conway 2008, 101.

49 See also Schnackenburg 1980, 387; Sanders \& Mastin 1968, 294; Morris 1995, 528-529. Cf. also John 18:11, where Jesus asks Peter "Am I not to drink the cup that the Father has given me?". 


\section{The Arrest of Jesus}

After the prayer in Gethsemane, a group of armed men led by Judas Iscariot comes to arrest Jesus (Mark 14:43-52; Matt 26:47-56; Luke 22:47-53). In Mark, Jesus henceforth begins to play a more passive role in the narrative. Starting with the arrest, Jesus is continually "handed over" ( $\pi \alpha \rho \alpha \delta i \delta \omega \mu l)$ and thus increasingly passive and feminized. ${ }^{11}$ Before Mark 14:43, Jesus has been the subject of most of the action, but after the arrest he becomes the object of most of the verbs. This also makes his few following speeches more striking. ${ }^{52}$ Passivity would make Jesus seem unmasculine, at least from the point of view of the self-assertive ideal of masculinity. Still, the silence and passivity of Jesus are not surprising, since at the end of his prayer struggle in Gethsemane, Jesus had resigned himself to God's will. However, Mark does not present Jesus as completely passive in the arrest scene. Jesus protests against being taken, and he holds the authorities responsible when a bystander violently resists arrest (Mark 14:48-49). ${ }^{53}$ This to some extent makes Jesus follow the self-assertive ideal of masculinity. On the whole, nevertheless, Jesus does not manage to come off as masculine from the point of view of self-assertive masculinity. In the end, Jesus is arrested without resistance.

The behavior of the disciples forms a contrast to Jesus. They first attempt to resist the arrest, which means that they again endorse the self-assertive ideal and have yet to understand Jesus' teaching of the inevitability of his suffering. When they fail to protect Jesus, they flee the scene. Trying to protect Jesus does not make the disciples negative examples, although it makes them proponents of the wrong type of masculinity. Fleeing the scene does make the disciples unmasculine from the point of view of the ancient Greco-Roman ideals, where the military virtue of $\alpha \nu \delta \rho \varepsilon i \alpha$ was defined as standing one's ground and not fleeing from the battle scene. Desertion was one of the most shameful acts a man could commit in the ancient Greco-Roman world. ${ }^{54}$ Unlike his disciples, Jesus does not try to escape or violently oppose the arrest. Earlier in the Gospel, Jesus has said that his arrest and death are a divine necessity, and now Jesus obeys God's will. In the arrest scene, Mark's ideal is closer to the Stoic ideal of endurance than the Aristotelian ideal of revenging wrongs.

\footnotetext{
$51 \quad$ Thurman 2003, 151.

52 Marcus 2009, 995-996.

53 Myers 2008, 367-368.

54 Miller 2000, 97-98. E.g., Plutarch, Sayings of Spartan Women 241B-C, 241F, 242A. See, however, Archilochus, fr. 6.5; Horace, Carm. 2.7.9-12, who both mention throwing away their shield and running away from battle.
} 
Matthew makes Jesus more in control of the arrest scene than Mark, and as a result he also makes Jesus appear more masculine. Jesus reacts to both Judas' kiss and the violent action of a disciple (Matt 26:50, 52-54). Jesus' speeches are also longer, which underlines the control that he has over the scene. He makes no attempt to resist arrest, but rather reprimands the disciples and those who have come to arrest him. In Matthew, Jesus' rebuke stresses that the disciples should not be violent. This is in accordance with Jesus' earlier teaching of not resisting an evildoer (Matt 5:39). Matthew thus presents Jesus as an example of his own teaching. Unlike Mark, who leaves Jesus' inaction unexplained, Matthew clarifies that the inaction is the result of Jesus' voluntary acceptance of his suffering. In Matthew, Jesus tells his disciples: "Do you think that I cannot appeal to my Father, and he will at once send me more than twelve legions of angels?" (Matt 26:53). Jesus' speech emphasizes the voluntary nature of his death. Accordingly, Mark's portrayal of Jesus is mitigated to some degree in Matthew and again moved closer to the ideal of the noble, masculine death. Jesus behavior is once more in contrast to that of the disciples, who desert Jesus. In Mark and Matthew, Jesus now has to face his death alone.

In Luke, Jesus is in control and dominates the scene. He stops Judas short before he has the chance to kiss him, rebukes the disciples, and heals the ear of the victim of violence (Luke 22:48, 51). Stopping to heal the victim not only allows Luke to show Jesus demonstrating his control, but also has him exhibiting clemency. As we will see, the theme of clemency continues throughout the passion narrative. Luke's portrayal of the disciples is also more favorable. The disciples do not flee. Accordingly, later the acquaintances of Jesus will witness the crucifixion (Luke 23:49). This not only improves the portrayal of the disciples, but the portrayal of Jesus. Jesus is not deserted, as in Mark and Matthew. Emphasizing Jesus' control and clemency enhances the depiction of Jesus displaying masculine features. Luke's account is even closer to the noble death tradition and makes Jesus more of an agent, instead of a passive victim.

In none of the Synoptic Gospels does Jesus try to escape the arrest. This is in accordance with the philosophical ideal of self-control and endurance. The philosophical writings often suggest that the ideal was to accept the necessity of death and not try to escape God's will. For instance, Socrates rejects Crito's offer of assistance to escape the death penalty. ${ }^{55}$ From the point of view of this tradition, Jesus appears masculine. Nevertheless, from the point of view of the self-assertive ideal of masculinity, Jesus' passive acceptance of the arrest makes Jesus unmasculine. 


\section{The Jewish and the Roman Trials: The Silence of Jesus}

After the arrest, Jesus faces two trials: the Jewish trial and the Roman trial. During both of these, Jesus is verbally and physically abused. I study the trials together because they have significant similarities. During both trials, Jesus remains silent and does not respond to the charges. Could this silence be interpreted as virtuous, masculine behavior? Public speaking and the ability to defend oneself in a trial were important facets of the ancient Greco-Roman masculinity, so Jesus' silence was problematic in this regard. Socrates, the Maccabean martyrs, and early Christian martyrs gave long speeches during their trials and executions.

In Mark, Jesus remains silent for the first part of the Jewish trial, while the chief priests and the whole council search for testimony against Jesus and find none (Mark 14:55-56). Mark uses a double negative to highlight Jesus' silence. ${ }^{56}$ Jesus responds only to the direct question from the high priest (Mark 14:62), giving an unequivocally affirmative answer that condemns him. During the Roman trial, Jesus gives a short, evasive answer to Pilate's question and then again remains silent when the high priests accuse him (Mark 15:2-5). In the Gospel of Matthew as well, Jesus initially remains silent in the Jewish trial and only briefly answers Pilate during the Roman trial (Matt 26:63; 27:11-14). The short answer that Jesus gives Pilate is the last time that Jesus speaks in Mark and Matthew before his last words on the cross.

Jesus' silence is again a sign that after Gethsemane, he has accepted his fate and does not wish to fight for his life. What does this silence mean for Jesus' masculinity? Not defending oneself could be seen as unmasculine. This is possibly the case in Mark and Matthew, when Pilate is amazed that Jesus does not answer the accusations (Mark 15:5; Matt 27:14). The most plausible interpretation is that Pilate is surprised that Jesus is not defending himself. ${ }^{57}$ Jesus thus acts in an unexpected way. Although there existed a wider precedence of victims suffering in silence, none of these themes are explicitly developed in the Synoptic Gospels. Moreover, as Eric Thurman notes, "more assertive, and hence more overtly 'masculine,' rhetorical tactics might be expected." Jesus' silence, as well as his lack of action, "opens him to charges of cowardice for failing to defend himself." ${ }^{n}$ This is true at least for the self-assertive ideal of masculinity. Jesus' silence would have made him seem unmasculine from the point

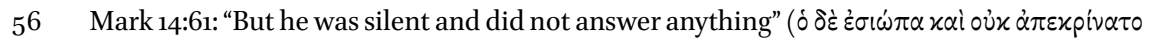
oủó́v).

57 See also Thurman 2003, 151; 2007, 212.

$5^{8}$ Thurman 2007, 211-213; see also Thurman 2003, 151.
} 
of view of this ideal. Mark and Matthew thus advocate an ideal of masculinity where following God's will is more important than following the prevalent ideals of masculinity.

On the other hand, Stephen Moore maintains that Jesus' silence could have been interpreted "as a bravura exercise of self-mastery" in a culture where selfcontrol was "the supreme index of masculinity." ${ }^{\text {99 }}$ Nevertheless, Luke's changes to Mark's text show that Jesus' silence was potentially problematic. Luke does not depict Jesus as silent. Instead, Jesus readily replies to the questions in both the Jewish and the Roman trials (Luke 22:66-23:5). Jesus is only silent before Herod (Luke 23:9), who nevertheless seems to have considered Jesus to be innocent (Luke 23:15). Luke's pro-Roman and apologetic tendencies are evident in the way he softens the Roman responsibility in the depiction of the trial. ${ }^{60}$ Jesus is declared innocent several times. The verdict against Jesus (Mark 14:64; Matt 26:66) is replaced by a threefold declaration of innocence (Luke 23:4, 14-15, 22). ${ }^{61}$ Luke intends to show that Jesus and early Christianity were not a threat to Rome. In addition to this apologetic motif, Luke also seeks to depict Jesus as more masculine. A. R. C. Leaney points out that had Jesus been silent in Luke's Gospel, it would have suggested to his readers that Jesus lacked an effective defense. ${ }^{62}$ Because Jesus is not silent, however, Luke differs from the more negative portrayal by Mark. Jesus can clearly defend himself, which is closer to hegemonic ideals of masculine portrayal.

\section{The Mocking and Scourging of Jesus}

During both trials, Jesus is physically and verbally abused. During the Jewish trial, Jesus is struck, spat on, and commanded to prophesy who hit him (Mark 14:65; Matt 26:67-68; Luke 22:63-65). In none of the Synoptic Gospels does Jesus answer anything to his abusers. He seems to be passively enduring the violence and mockery without uttering a word. In Matthew, this makes Jesus the exemplar of his teaching not to resist an evildoer (Matt 5:39). It is possible that Jesus' behavior would make him exemplarily self-controlled and thus masculine, but this theme is not explicitly developed in the Synoptic Gospels.

The scourging or disciplining of Jesus is mentioned in all of the Synoptic Gospels as part of the Roman trial. In the Roman judicial system, this

\footnotetext{
59 Moore 2003, 11. See also Malina \& Rohrbaugh 1998, 264; Neyrey 1996, 114; Pilch 1995, 68.

6o Matthews 2005, 132.

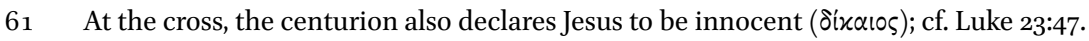

62 Leaney 1971,275 .
} 
punishment was meted out either as a warning not to continue causing trouble, as part of inquisitional torture to obtain a confession, or as part of the capital sentence. The Romans used three words to describe the punishment: fustigatio (beating), flagellatio (flogging), and verberatio (scourging). The first of these was a punishment in itself, whereas the last two were used as part of the capital sentence. ${ }^{63}$

In Mark and Matthew, Jesus is flogged before the crucifixion (Mark 15:15;

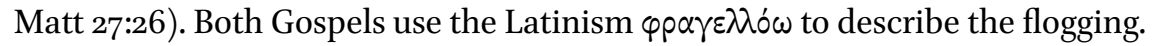
The verb refers to flogging as part of the capital sentence. Crucifixion was usually preceded by flogging or scourging. ${ }^{64}$ However, the narratives do not dwell on this flogging; it is mentioned in a subordinate clause. The accounts concentrate instead on the mocking of Jesus by the soldiers. The soldiers clothe Jesus in the typical insignias of a king, a purple cloak and a crown, and salute him as the "King of the Jews." They also strike his head with a reed, spit on him, and kneel down in mock homage to him (Mark 15:17-19; Matt 27:27-31). The accounts focus more on dishonor than physical pain. Jesus' reaction to this abuse is not depicted this time either. Again Jesus may be understood as exhibiting self-control, but this theme is not the explicit concern of Mark and Matthew.

In Luke, verses 23:16 and 22 are the only references to the beating of Jesus. Luke does not use the same word as Mark and Matthew; instead he uses $\pi \alpha \iota \delta \varepsilon v$ w, which means "to discipline, punish." ${ }^{65}$ Luke thus suggests the lightest form of the beating (fustigatio), the one given as a warning. ${ }^{66}$ Whether this disciplining actually happened is not clear. Nor is Jesus mocked by the Romans here. Instead, Luke transfers the mocking to Herod and his soldiers (Luke 23:11). This is clearly part of Luke's attempt to tone down the punishment. He may have also wished to exonerate the Romans.

In sum, in Mark and Matthew Jesus' scourging is part of the crucifixion. In Luke, it is disciplining, a form of lesser punishment, and it is not even clear if it ever happens. ${ }^{67}$ How would this treatment affect Jesus' masculinity and can Jesus' behavior during the mocking and physical abuse be seen as masculine?

63 For ancient sources, see, e.g., Acts 16:22; 22:24-25; Josephus, J.W. 2.306-308; 5.449; 7.200203; Livy 1.26.6; 28.37.3; 33.36.3; Philo, Flaccus 9.72; 10.75; 10.84; Dio Chrysostom, Or. 4.67; Apuleius, Metam. 3.9.1; Horace, Sat. 1.3.119. See also Brown 1970, 876; 1994a, 851-852; Keener 1999, 672; Lane 1975, 557; Walaskay 1975, 91.

64 See, e.g., Plato, Gorg. 473b-c; Resp. 361e-362a; Livy 28.37.3; 33.36.2; Josephus, J.W. 2.306308; 5.449; 7.200-203; Philo, Flaccus 9.72.

65 Cf. Hos 7:12 LXX.

66 Walaskay 1975, 90-91.

67 See also Glancy 2005, 121-122. 
Protecting bodily boundaries and the inviolability of the body were important aspects of the ideal masculinity in the ancient Greco-Roman world. Slaves, noncitizens, prisoners of war, convicted criminals, and conquered foreigners-in other words, groups that were not fully men — could legitimately be beaten. ${ }^{68}$ Richard Saller notes that more was at stake with corporal punishment than mere physical pain. More important was the deep humiliation that the act caused. ${ }^{69}$ It was an outrage if a free citizen man was hit, since it associated him with the treatment of slaves. ${ }^{70}$ Aristotle, for example, argued that an inability to defend oneself was disgraceful. Meek endurance and the absence of resistance were signs of unmanliness. ${ }^{71}$ Aristotle also argued that one is not "courageous if he shows a bold face when about to undergo a flogging."72 However, some philosophers, especially in the Stoic tradition, saw the endurance of suffering as the ideal masculine deportment. Seneca, for example, maintained that abuse is not shameful. ${ }^{73}$ According to this self-controlled ideal, the endurance of physical abuse would make a man more masculine than retribution of wrongs.

Some scholars argue that Jesus stoically endures physical abuse. Silence may imply endurance and Stoic perseverance. ${ }^{74}$ Jesus' behavior would thus be in accordance with the self-controlled ideal and close to the ideal of the noble, masculine death. ${ }^{75}$ However, Celsus did not interpret Jesus' silence during torture in this way. Instead he presents the examples of Anaxarchus and Epictetus, who spoke calmly under torture, and asks: "What saying equal to

68 Glancy 2002, 25; 2004, 108-111; Grig 2002, 325; Richlin 1999, 196; Saller 1991, 153; Walters 1997, 30.

69 Saller 1991, 151-153.

70 See, e.g., Demosthenes, Against Meidias 21.178, 180; Against Androtion 22.53-55.

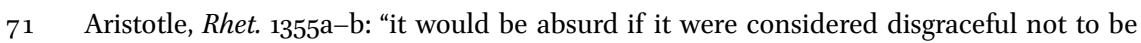
able to defend oneself with the help of the body, but not disgraceful as far as speech is concerned, whose use is more characteristic of man than that of the body." Aristotle, Rhet. 1384a2o: "meek endurance and the absence of resistance are the result of unmanliness or cowardice." Transl. John Henry Freese.

72 Aristotle, Eth. nic. 1115a20-25. Transl. H. Rackham.

73 E.g., Seneca, Ep. 67; 85.27; Seneca, Const. 16.1-2. See also Epictetus, Diatr. 3.22.54: if flogged, a Cynic "must love the men who flog him." Transl. W. A. Oldfather. Cf. Epictetus Diatr. 2.2.13.

74 Neyrey $1998,150$.

75 Glancy (2004) notes that there are other New Testament texts, such as in 2 Cor 11:23-25 and Acts 5:40-41, where corporal punishment is mentioned in a positive light. 
these did your god utter under suffering?"76 Jesus' silence could thus be interpreted as passivity. Origen, nevertheless, read it as a sign of courage. For

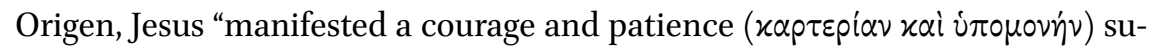
perior to that of any of the Greeks who spoke while enduring torture."77 From the point of view of the self-assertive ideal of masculinity, in any case, Jesus' behavior is not masculine. During the scourging, Jesus is not in control of his bodily boundaries and he does nothing to prevent the punishment from taking place. The proponents of the self-assertive ideal of masculinity would not have seen Jesus as masculine. From the point of view of the self-controlled ideal, Jesus could be considered masculine, but Celsus' example shows that this is not self-evident either.

\section{The Crucifixion and Death of Jesus}

The Synoptic Gospel accounts of the crucifixion are reticent to go into detail. Mark and Luke mention it in passing (Mark 15:24; Luke 23:33), and Matthew brushes over the event in a subordinate clause (Matt 27:35). This is in contrast with 4 Maccabees, for instance, where the torture of the seven brothers is recorded in merciless detail..$^{78}$ One reason for this reticence could be the humiliating nature of crucifixion. For the ancient Greco-Roman people, crucifixion was utterly offensive and shameful. ${ }^{79}$ It was the typical punishment for slaves

76 Origen, Cels. 7.53: "At any rate you had Anaxarchus who, when cast into a mortar and while he was being beaten with great violence, nobly showed contempt for the punishment, saying 'Beat on, beat the pouch of Anaxarchus, for you are not beating him.' The utterance is surely one of some divine spirit. But some natural philosophers have preceded you in taking him for their master. What about Epictetus then? When his master was twisting his leg he smiled gently and calmly said 'You are breaking it.' And when he had broken it he said 'Did I not tell you that you were breaking it?' What comparable saying did your God utter while he was being punished?" Transl. Henry Chadwick. See also Collins 1994, 482.

77 Origen, Cels. 7.55. Transl. Henry Chadwick.

78 E.g., 4 Macc 5:16-38; 6:17-29; 9:15-12:19.

79 For ancient attitudes toward crucifixion, see, e.g., Plato, Gorg. 473b-c; Resp. 361e-362a; Cicero, Verr. 2.5.162-169; Pliny the Elder, Nat. 28.11.46; Epictetus, Diatr. 2.2.20; Diodorus Siculus 14.53.4; Curtius Rufus, History of Alexander 4.4.17; Livy 28.37.3; 33.36.2; Apuleius, Metam. 1.14.2; Plautus, Capt. 469; Cas. 611; Men. 66, 849; Poen. 347; Pers. 352; Rud. 518; Trin. 598; Josephus, J.W. 7.200-203; Philo, Flaccus 9.72; Posterity 61; Dreams 2.213; Origen, Cels. 6.10; Justin, 1 Apol. 13.4. In the New Testament as well, it was admitted that crucifixion was a shameful way of dying, cf. Heb 12:2; 1 Cor 1:23. See also Cook 2014; Green 1997, 810; Hengel 1977, 22, 64-68; Pilch 1995, 65. 
and criminals. ${ }^{80}$ Physical torture was not the only reason why this death was so despicable. The public humiliation made it even more so. ${ }^{81}$ The condemned was crucified while naked, which further added to the shame..$^{82}$ The inability to control one's bodily boundaries, as well as the loss of power, made the condemned unmasculine. Mark's and Matthew's accounts of the crucifixion and the death of Jesus are relatively similar to each other. Therefore, in the following I study the accounts of Mark and Matthew together and examine Luke's account separately after that.

\section{The Death of Jesus in Mark and Matthew}

After the trials and the scourging, the soldiers take Jesus to the place of crucifixion (Mark 15:20-22; Matt 27:31-33). They have to enlist Simon to carry the cross. William Campbell claims that in the Gospel of Mark, Jesus actively tries to obstruct the sentence from taking place by refusing to bear the cross. The soldiers are forced to carry Jesus to the place of execution. Campbell bases

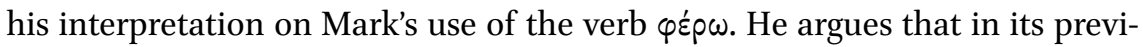
ous occurrences in Mark, the term means literal or figurative "carrying," when the person could not or would not move independently. ${ }^{83}$ If Jesus was actively resisting the crucifixion, it would make the portrayal more in line with the selfassertive ideal of masculinity. However, if Jesus refused to carry the cross, he would be doing this against the will of God. Active resistance of the sentence may be more masculine according to the self-assertive ideal of masculinity, but not according to the ideal masculinity of Mark's Gospel. In addition, as Adela Yarbro Collins notes, $\varphi \varepsilon \rho \omega$ does not necessarily mean literal carrying; it can also mean that other people took the initiative. Collins concludes that Jesus was thus subordinated to the soldiers, and it was their initiative to move to Golgotha. ${ }^{84}$ Therefore, it is more likely that Jesus did not obstruct the sentence but possibly was too weak to carry the cross. This would call his masculinity into question.

$80 \quad$ See, e.g., Plautus, Mil. glor. 372-373; Bacch. 362; Juvenal, Sat. 6.219. See also Hengel 1977, 51-57; Neyrey 1998, 139.

$81 \quad$ Watson 2010, 69 .

82 Cf. Plutarch, The Roman Questions 274A. Especially for Jews, naked execution was shameful; Gen 3:7, 10-11; Jubilees 3:21-22, 30-31; 7:8-10, 20.

83 Campbell 2004, 294-295.

84 Collins 2007, 737-738. Collins points out that the deaf man in Mark 7:32 and the blind man in Mark 8:22 needed assistance, not carrying. In both of these cases, the implication is that "other people took the initiative and the man in need of healing was subordinated to them." Moreover, in Mark 2:3 another verb, $\alpha$ i $p \omega$, is needed to describe the actual carry-

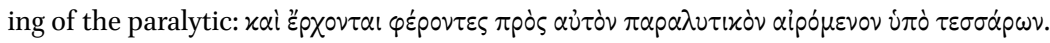


In Mark, Jesus is offered wine with myrrh (Mark 15:23), which was probably intended to dull the pain of crucifixion. ${ }^{85}$ Jesus refuses, possibly because he is determined to go to his death with full consciousness. The rejection of the drink stresses the voluntary nature of Jesus' death. Here Mark is close to the Stoic ideal of despising pain. Jesus' voluntary death would make him seem masculine from the perspective of the Stoics and the noble death tradition. In Matthew, the wine is spiked with gall $(\chi \circ \lambda \eta)$, which probably made the wine undrinkable (Matt 27:34). The drink thus becomes one more example of abuse by Jesus' opponents. ${ }^{86}$ It emphasizes Jesus' passivity and suffering and does nothing to make Jesus appear more masculine.

The accounts of the crucifixion itself are restrained. Like in the flogging scene, Mark and Matthew instead concentrate on the humiliation of Jesus. The soldiers strip Jesus of his clothes and divide them (Mark 15:24; Matt 27:35). The passersby, high priests, and scribes, as well as the criminals who were crucified with Jesus, deride Jesus with humiliating gestures and words (Mark 15:29-32; Matt 27:39-44). For the outsiders, Jesus' death is shameful and shows that his claims to status are wrong. They suggest that Jesus should show his claims to be correct by coming down from the cross. The outsiders see Jesus' death as a sign that he has been a failure as God's representative. For Mark and Matthew, on the contrary, Jesus' refusal to "save himself" demonstrates Jesus' royal status, since it benefits people and saves them. ${ }^{87}$ If Jesus does not descend from the cross, he passes the test of his own teaching. ${ }^{88}$ The outsiders represent the self-assertive ideal that considers a man who is unable to defend himself to be unmasculine. Mark and Matthew, on the contrary, are closer to the ideal of the noble death, which considers voluntary death and enduring suffering as masculine ideals.

After several hours of silence, Jesus speaks by quoting Psalm 22:2: "My God, my God, why have you forsaken me?" In Matthew, the last words of Jesus are almost the same as in Mark. Jesus has not spoken since his brief answer to Pilate. Nothing in the narrative has prepared for this cry of abandonment. Accordingly, some scholars have suggested that Jesus has all of Psalm 22 in mind and that the quotation should be understood as a confident prayer. ${ }^{89}$ However, Brown notes that although it can be supposed that Hebrew Bible citations were

\footnotetext{
85 In Dioscorides Pedanius' pharmaceutical, De materia medica 1.77, wine mixed with myrrh is referred to as an anesthetic or narcotic.

86 Cf. Ps 68:22 LXX. See also Brown 1994b, 943; France 2007, 1067; Nolland 2005, 1191.

87 Cf. Mark 8:35; 10:45; Matt 16:25; 20:28.

88 Marcus 2009, 1052; Luz 2005, 537-538.

$89 \quad$ E.g., Donahue \& Harrington 2002, 451.
} 
familiar to readers, in this case "it would mean that Mark expected his readers to recognize that a psalm was being cited, to know the whole psalm, and to detect from a reference to the agonized opening verse the triumphant fate of the one who prays." In other words, Mark and Matthew would have expected the readers to come to exactly the opposite meaning than what they wrote. ${ }^{90}$ Moreover, there is nothing in the narrative that shows God as being on Jesus' side: Jesus has been abandoned by his disciples and is mocked by passersby. ${ }^{91}$ It is better to take the quotation literally as a cry of abandonment.

Jesus lets forth a loud cry ( $\dot{\alpha} \varphi \varepsilon i \varsigma ~ \varphi \omega \nu \eta \dot{\nu} \mu \varepsilon \gamma \alpha \dot{\lambda} \lambda \eta \nu)$ right before he dies (Mark 15:37; cf. Matt 27:50). Robert Gundry argues that the loudness emphasizes Jesus' superhuman strength. ${ }^{92}$ However, Mark could have emphasized Jesus' strength in some other, more masculine, way. As Colleen Conway notes, "surely there are more straightforward ways to display manliness, strength, and courage in a death scene." ${ }^{93}$ The expression refers to a tortured rather than a voluntary action. ${ }^{94} \mathrm{G}$. W. Bowersock maintains that the cry is "utterly at variance with the standards of the Graeco-Roman society."95 Although Cicero remarks that "sometimes, though seldom, it is allowable for a man to groan aloud," the brave and wise man (virfortis ac sapiens) does not do even that. Only in exceptional cases should a man indulge in a groan, but Cicero still doubts whether it is useful. Cicero questions why one would disgrace oneself when it does nothing to abate the pain. ${ }^{96}$ In the end, therefore, Cicero finds groaning in pain to be questionable behavior for a man: "if the groan is melancholy, weak, despondent, piteous I can scarcely give the name of man to him who has succumbed." Jesus' cry makes his masculinity questionable. ${ }^{97}$

Jesus' last words are not a trusting and confident prayer to God, like the prayers of the Maccabean martyrs, or, as we shall see, like Jesus' last words in the Gospel of Luke. His last words are also in contrast to the peaceful death of Socrates and the philosopher's ironic last words. Moreover, Mark's and Matthew's accounts differ from the later accounts of the deaths of early Christian martyrs. Mark and Matthew do not model Jesus' manner of dying reason to interpret Matthew's psalm quotation differently from Mark.

$91 \quad$ Brown 1994b, 1045-1046.

$92 \quad$ Gundry 1993, 947, 970.

93 Conway 2008, 102.

94 Brown 1994b, 1081.

95 Bowersock 1994, 74.

96 Cicero, Tusc. 2.55-57. Transl. J. E. King.

97 This is also noted by Conway 2008, 102. 
after the noble death tradition. ${ }^{98}$ The way in which Jesus dies would have been considered unmasculine by both the self-assertive and self-controlled ideals of masculinity. What does this mean for the masculinity presented in the Gospels of Mark and Matthew? They do not present Jesus' death in accordance with the noble death tradition, which would be complicit with the self-controlled ideal. As we will see, this is what Luke does. Mark and Matthew, on the contrary, seem to advocate a voluntarily marginal ideal of masculinity.

\section{The Death of Jesus in Luke}

Luke's account of Jesus' crucifixion and death is notably different from Mark's and Matthew's accounts. Luke portrays Jesus as calm before death, facing death with confidence and courage. David Liberto maintains that Luke's intention was to present his readers with the proper attitude to death. ${ }^{99}$ As we will see, Luke's account is close to the philosophical ideal of a noble death. Having a proper attitude to death also meant dying like a man. Luke changes several details of Mark's text to accomplish this goal. The themes of forgiveness and clemency are also important for Luke's narrative of Jesus' crucifixion and death.

Unlike in the Gospels of Mark and Matthew, where Jesus does not speak after his brief answer to Pilate until his last words on the cross, in the Gospel of Luke Jesus speaks several times on his way to Golgotha and while on the cross. The scourging of Jesus is not mentioned, but Simon is still enlisted to carry the cross (Luke 23:26). On the way, Jesus addresses women, who are lamenting for him (Luke 23:27-31). Thus, in Luke's narrative Jesus is not as passive as in Mark and Matthew, but more in control of events. The depiction of the journey to the place of crucifixion seems more like a dignified procession. ${ }^{100}$ Luke also adds dialogue between the criminals and Jesus on the cross (Luke 23:39-43). All of these changes make Jesus' death more voluntary and closer to the ideal of the noble, masculine death.

Luke mentions that a large crowd was following Jesus (Luke 23:27). The crowds are not depicted as mocking Jesus. Instead they beat their breasts when returning home after Jesus' death (Luke 23:48). Jesus' acquaintances, not just

\section{Collins 2007, 754 .}

99 Liberto 2003, 219-220.

100 Wilson $(2015,230)$ argues that since Simon carries Jesus' cross, Luke is probably suggesting that Jesus was scourged and is too weak to carry the cross. However, since Jesus is able to hold a conversation with the women on the way, the scene seems to instead highlight Jesus' dignity. Moreover, Simon carries the cross "behind Jesus," which makes him an example of discipleship; cf. Luke 14:27. 
women, are also watching the crucifixion (Luke 23:49). ${ }^{101}$ As a result, there are more sympathetic figures at the crucifixion, and Jesus does not die alone and abandoned like in Mark and Matthew. The high priests and soldiers mock Jesus, but this does not receive as much emphasis as in Mark and Matthew. Luke instead emphasizes Jesus' control over events. Jesus is forgiving and speaks on the cross several times. Besides forgiving the criminal that is crucified next to him, Jesus also forgives the crucifiers. When he is crucified, Jesus prays: "Father, forgive them; for they do not know what they are doing" (Luke 23:34). While this verse is absent from some manuscripts, ${ }^{102}$ it is easier to presume that Luke wrote the prayer than to presume that a later scribe added the prayer in Luke's style. ${ }^{103}$ The similarities with Stephen's prayer at his death (Acts 7:60) also point to the originality of the verse. ${ }^{104}$ The verse is thus probably original.

Jesus' prayer is connected to the virtue of clemency (clementia), which was a peculiarly Roman virtue. ${ }^{105}$ The word clementia, used in the contexts of war and law courts, meant sparing a conquered enemy or mitigating the sentence of a convict. ${ }^{106}$ Thus, it was connected with self-control, ${ }^{107}$ which also made it a masculine virtue. Seneca argues that whereas misericordia was a womanish emotion of pity for the unfortunate, clementia was combined with rationality.

[...] good men (boni viri) will all display mercy and gentleness (clementiam mansuetudinemque), but pity (misericordiam) they will avoid; for it is the failing of a weak nature that succumbs to the sight of others' ills. And so it is most often seen in the poorest types of persons; there are old

101 Wilson $(2015,232-233)$ argues that since the disciples are watching the crucifixion from a distance, this represents a negative portrayal of the disciples. However, Luke's tendency to enhance the portrayal of the disciples makes it more likely that here as well he is trying to make their portrayal more positive in comparison to Mark.

102 The prayer is absent from, e.g., $\mathrm{p}^{75} \boldsymbol{\aleph}^{1} \mathrm{~B}$ D W, but it is found in, e.g., $\boldsymbol{\aleph}^{*},{ }^{2}$ A C D L. Matthews $(2009,122-123)$ notes that the patristic evidence for the verse is also substantial.

103 Brown 1994b, 980.

104 See Matthews 2010, 101. Matthews suggests that an increase in anti-Jewish sentiment was the motive for the scribes to leave this verse out. The problem of the verse for the scribes was that Jesus not only prayed for forgiveness for Jews, but for undeserving and unrepentant Jews. Matthews 2009, 124; 2010, 102. A similar argument is also made by Brown 1994b, 979 .

105 In Greek, $\varphi i \lambda \alpha \nu \theta \rho \omega \pi i \alpha$ and $\pi \rho \alpha \tilde{u} \pi \eta \varsigma$ imply forgiveness, which is close to the meaning of clementia, but their primary usage denotes benevolence or gentleness respectively.

Dowling 2006, 4.

106 Dowling 2006, $5^{-6 .}$

107 Matthews 2009, 142-144; 2010, 118-119. 
women and wretched females (anus et mulierculae) who are moved by the tears of the worst criminals, who, if they could, would break open their prison. Pity regards the plight, not the cause of it; mercy is combined with reason. ${ }^{108}$

Clemency was an act of power. Only those in a position of exacting revenge could choose to exercise clemency. ${ }^{109}$ This made clementia the virtue of elite men, since women, slaves, and foreigners did not have the power or right to dispense clemency. ${ }^{110}$ Seneca, for example, notes that clementia separates the elite self-controlled ruler from women and wild beasts. ${ }^{111}$ Since clemency was connected to vertical power, it was the ideal virtue of the emperor. This is most evident in Seneca's De Clementia, where Seneca urges Nero to act with clemency. ${ }^{112}$

Shelly Matthews notes that Jesus acts like an emperor throughout Luke's passion narrative. He is in complete control of his emotions in Gethsemane and he remains in control over events. His prayer of forgiveness for the crucifiers and his granting of forgiveness to a criminal distinguish him as a true emperor, who has the right and power to display clemency. It is important to note that in Roman discourse, the clemency shown in Jesus' prayer for mercy was not a sign of passivity, submission, or humility. Rather, the prayer should be understood as an act of power. ${ }^{113}$ Jesus is not passive, but exercises power over his executors. What makes the narrative unusual is that the one exhibiting clemency is a convicted criminal. However, Matthews also notes that Jesus appeals to God to grant forgiveness, which an emperor does not have to do since he himself authorizes the pardon. ${ }^{114}$ In Luke, God takes the place of the emperor. This emphasizes the masculine piety of Jesus.

Although Seneca considered clementia to be masculine, this was not the only interpretation of mercy. Matthews notes that in the Greco-Roman culture, clementia - or refraining from administering punishment-could be interpreted as a violation of justice and thus as an example of the womanish vice

\footnotetext{
108 Seneca, Clem. 2.5.1. Transl. John W. Basore. See also Seneca, Clem. 2.4.4.

109 See, e.g., Seneca, Clem. 1.21.1; 2.3.1. Dowling 2006, 17-18; Matthews 2009, 142, 144; 2010, 118-119.

110 Dowling 2006, 17-18, 27.

111 Seneca, Clem. 1.5.5.

112 See, e.g., Seneca, Clem. 1.3.2: "for all men none is better graced by mercy than a king or a prince. For great power confers grace and glory only when it is potent for benefit." Transl. John W. Basore. Cf. Cicero, Off. 2.22-24; Seneca, Clem. 1.5.6.

113 Matthews 2009, 144-145; 2010, 120-121.

114 Matthews 2010, 120.
} 
of pity, misericordia. ${ }^{115}$ Therefore, not even all of the Stoic philosophers accepted clemency. Traditionally, the Stoics opposed clemency because it withholds the penalty that the guilty deserves to suffer. Thus, clemency is not just, but an emotional impulse not guided by reason. ${ }^{116}$ As a result, it is possible that some ancient Greco-Roman readers interpreted Luke's depiction of Jesus' clemency as showing that Jesus is behaving in an unmasculine way. Nevertheless, since Luke's depiction of Jesus' behavior is close to the ideal masculinity presented by Seneca, it is also possible that from the point of view of the selfcontrolled ideal of masculinity, Luke's portrayal of Jesus would have been understood as masculine.

As mentioned above, Luke wants to present what it means to have a proper attitude to death. In order to do this, Luke reshapes the tradition by emphasizing the calmness of Jesus. The calmness of Jesus in his death can be seen, for example, in how Luke softens Jesus' last words. Luke omits the cry of abandonment, replacing it with an "affirmation of dedication."117 Instead of "My God, my God, why have you forsaken me," Jesus quotes Psalm 31:6 and prays "Father, into your hands I commend my spirit." The last words of Jesus emphasize the voluntary nature of his death. ${ }^{118}$ Not only are the words that Jesus utters important, but also the manner in which he speaks them. In Mark and Matthew, the scene is full of anguish and desolation. The verb that Luke uses to describe Jesus' speech is different. In Mark, Jesus "cries out" ( $\beta \circ \alpha ́ \omega)$, a verb Mark also uses for the evil spirits when Jesus exorcizes them. Mark's verb describes a violent action. Luke's use of $\varphi \omega \nu \varepsilon \hat{\varepsilon} \omega$ ("speak loudly") avoids the sense of despair and anguish. ${ }^{119}$ Unlike in Mark and Matthew, in Luke Jesus' death is peaceful. His trust in God never wavers. ${ }^{120}$ Emphasizing the calmness and peacefulness of Jesus makes him like Socrates and other philosophers, who died a noble death. This depiction also removes emotional elements from Jesus' death, which, as we have seen, is part of a larger pattern in Luke. Both emphasizing calmness and removing the emotional elements move Luke's narrative in the direction of Stoic philosophical accounts of a good death. ${ }^{21}$ Luke transforms

\footnotetext{
115 Matthews 2010, 25-26, 100, 122.

116 Dowling 2006, 202. Cf. Seneca, Clem. 1.2.1.

117 Sterling 2001, 395-396.

118 Plummer 1981, 538.

119 Brown 1994b, 1067; Liberto 2003, 220-221.

120 Green 1997, 812.

121 See also Sterling 2001, 397-398.
} 
Jesus' embarrassing crucifixion into an exemplary noble death. ${ }^{122}$ Once more, Luke's account of Jesus' death is closer to the ideal of the noble death than Mark's and Matthew's passion narratives.

\section{Conclusions}

Out of the Synoptic Gospels, Mark emphasizes the humiliating elements of Jesus' death the most. Mark depicts Jesus as not defending himself in the trials and silently suffering abuse and the crucifixion. In these instances, Mark may be employing the tradition of the noble, masculine death. However, Jesus' emotional behavior in Gethsemane and his loud cry from the cross make this interpretation questionable. Matthew occasionally emends Mark's account. For example, he changes Jesus' prayer in Gethsemane. As a result, Matthew's depiction of Jesus is closer to the ideals of the noble, masculine death. Nevertheless, Matthew does not change the narrative of Jesus' trials and death. Jesus' death is still not in accordance with the ideals of the noble death. Luke, on the other hand, changes Mark's narrative considerably and thus moves it clearly in the direction of the ideal of the noble, masculine death. Jesus is not emotional in Gethsemane, defends himself in the trials, and remains confident and calm on the cross.

Protecting one's bodily boundaries and not allowing humiliation by others were key features of the ancient Greco-Roman self-assertive ideal of masculinity. Mocking, abuse, flogging, and crucifixion were all shameful. In the Synoptic Gospels, Jesus' body is violated and he is humiliated, yet he does nothing to stop the violence and abuse from happening. Jesus is a passive victim. At least from the point of view of the self-assertive ideal of masculinity, this can be seen as a sign of effeminacy. Jesus comes off as passive, especially in the accounts of Mark and Matthew. Luke, on the other hand, depicts Jesus more in control over events. In this way, Luke preserves Jesus' masculinity. Nevertheless, in none of

122 See also D’Angelo 1990, 453; 1999, 187; Sterling 2001, 384; Syreeni 1991, 36-57. Unlike most scholars, Wilson (2015, 190-191) comes to the conclusion that Luke does not portray Jesus' death as a noble death. Wilson argues that "[a]s someone who dies the death of convicted criminal, Jesus has lost his claims to manhood as well." Wilson 2015, 231-232. Wilson thus emphasizes the importance of the manner of execution over the way in which Jesus faces death in Luke's Gospel. However, a shameful mode of execution does not necessarily result in a loss of masculinity if one dies in the right way. Comparison with the other Synoptic Gospels shows that Luke has changed Mark's narrative in ways that make Jesus' death seem more like a noble death. 
the Synoptic Gospels does Jesus succeed in protecting his masculinity in the way in which self-assertive masculinity maintained to be the ideal.

The noble death tradition, on the other hand, emphasized the importance of self-control as a masculine ideal. Jesus' silent endurance could have been a sign of masculinity to the proponents of the self-controlled ideal of masculinity. As we have seen, however, Celsus used the standard of the noble death to judge the passion narratives and he found Jesus wanting. In addition, Jesus' manner of dying and especially his loud cry before death appear to be less self-controlled and thus less masculine. At least in the Gospels of Mark and Matthew, Jesus appears unmasculine from the point of view of both the selfassertive and self-controlled ideals of masculinity. He does not protect his bodily boundaries or avenge his injuries, and he does not show signs of self-control in his emotional behavior in Gethsemane or his loud cry on the cross. Luke, on the other hand, again preserves Jesus' masculinity by presenting him as more calm and self-controlled in his death. Luke's ideal masculinity is thus closer to the ideal of the noble, masculine death in the ancient Greco-Roman world.

Although Luke tries to preserve Jesus' masculinity by moving it closer to the self-controlled ideal, crucifixion as the method of Jesus' death meant that the death itself remained shameful. ${ }^{123}$ When Jesus dies willingly, the Synoptic Gospels reframe Jesus' shameful death on the cross as a victory over death. This is especially evident in Luke's depiction of Jesus' behavior in Gethsemane and his last, confident words on the cross. Nevertheless, Mark and Matthew also maintain that Jesus cannot save himself, since the one who attempts to save his life will lose it (Mark 10:35; Matt 16:25; Luke 9:24). The voluntary nature of death makes Jesus' death masculine. That Jesus' death was not shameful is proved when God resurrects him. The resurrection and the miraculous events that accompany Jesus' death are signs of God's vindication of Jesus. For the writers of the Synoptic Gospels, this vindication also confirms Jesus' masculinity. The resurrection moves Jesus closer to the more masculine divine realm. It is notable that Mark's original narrative does not include "masculinizing" appearances of the resurrected Jesus. In Mark, Jesus' masculinity remains questionable. ${ }^{124}$ Other differences can be seen in the ways in which the Synoptic Gospels depict Jesus' death. Mark's and Matthew's accounts of the passion narrative present a more voluntarily marginalized masculinity, whereas Luke is more complicit with the ideal of self-controlled masculinity.

123 Cf. 1 Cor 1:23. This is noted also by Klinken \& Smit 2013, 11-12.

124 See also Merenlahti 2015, 152. 
It is difficult to say whether ancient Greco-Roman readers would have considered Jesus to be masculine. The answer probably depends on their social position and what ideal of masculinity they advocated. It is unlikely that those who favored self-assertive masculinity would have considered Jesus to be masculine. Those who favored the self-controlled ideal of masculinity might have seen Jesus' way of dying as masculine in Luke's Gospel, but not in Mark or Matthew. However, a male slave may have found attractive the idea that corporal vulnerability did not compromise masculinity. Thus, the Synoptic Gospels' way of portraying Jesus' death may have led readers to rethink what masculinity entailed. 